\title{
Tanulmányok
}

\section{A LÉLEKTAN ALAKULÁSA 1945-1948 KÖZÖTT A BUDAPESTI BÖLCSÉSZKARON}

\section{THE FATE OF PSYCHOLOGY BETWEEN 1945-1948 AT THE BUDAPEST FACULTY OF SOCIAL SCIENCES AND HUMANITIES}

\author{
Pléh Csaba \\ az MTA rendes tagja, Közép-európai Egyetem Kognitív Tudományi Tanszéke, Budapest \\ vispleh@ceu.edu
}

\begin{abstract}
ÖSSZEFOGLALÁS
Az 1945-49 közötti időszakban a Budapesti Tudományegyetemen több lépésben szerveződött újra a pszichológia. A tanulmány levéltári források alapján bemutatja, hogy kezdetben az 191819-ben a Pszichológiai Tanszéket megalapozó, Amszterdamban dolgozó Révész Gézát próbálták mind a vele jó kapcsolatot ápoló konzervatív filozófusok (Kornis Gyula), mind az új baloldali professzorok (Lukács György) megnyerni a hazatérésre. Ennek kudarcát követően Várkonyi Hildebrand Dezső eredetileg szegedi, akkor már műegyetemi professzor kapott megbízást egy évre, hogy azután Kardos Lajos kísérleti pszichológus vegye át a lélektan vezetését a sivatagon átkelés nehéz sztálini éveiben. Ő is, akárcsak a nehéz évek más főszereplői, Mérei Ferenc és Molnár Imre, a numerus clausus miatt külföldön szocializálódott üldözött zsidó szakemberek voltak, akik Szondi Lipót tanítványaként váltak a hálózatépítés mestereivé.
\end{abstract}

\section{ABSTRACT}

Psychology was reorganized at the Budapest University in several steps between 1945 and 1949. The paper shows on the basis of archival materials that in the beginning both conservative philosophers (Julius Kornis) who were in close professional contact with him, both newly appointed left wing professors (George Lukács) wanted to invite Géza Révész, founder of the Psychology Department in 1918-19, back to Budapest, who at the time was working in the Amsterdam University. After the failure of this invitation Dezső Hildebrand Várkonyi, originally from Szeged University, but at the time working at the Budapest University of Technology was invited for about a year. This was followed by the appointment of Lajos Kardos, the experimental psychologist as an associate professor and chair of psychology during the harsh years of 'traversing the desert' of Stalinist years. Kardos like other key players of the difficult years, Ferenc Mérei and Imre Molnár, were Jewish professionals socialized abroad due to the numerus clausus, the discriminatory university entrance regulations, who have become masters of network building as students of Leopold Szondi after returning to Hungary. 
Kulcsszavak: Eötvös Loránd Tudományegyetem, magyar pszichológia, Révész Géza, Kornis Gyula, Kardos Lajos, Várkonyi Hildebrand Dezső, Molnár Imre, Szondi Lipót

Keywords: Loránd Eötvös University, Hungarian psychology, Géza Révész, Gyula Kornis, Lajos Kardos, Dezső Hildebrand Várkonyi, Imre Molnár, Leopold Szondi

Dolgozatomban azt tekintem át, hogy 1945-ben, röviddel a felszabadulást követően hogyan alakult a pszichológia újjászervezése a Budapesti Egyetem Bölcsészkarán - a közismert névváltozások miatt használom a semleges leíró nevet. (A tágabb távlatokra jó forrás Hunyady György két előadása, 2006a,b.) Milyen feszültségek között éltek, Révész Géza visszatérésére várva, a különböző várakozók és pályázók? Hogyan jelentek meg a lélektan felújításának törekvései a korabeli Kari Tanács és Egyetemi Tanács jegyzőkönyveiben, és hogyan vált 1949-re kiformálttá a győztesek hálózata, a Kommunista Párt ernyőjét élvező pszichológusok új világa. Forrásaim elsősorban az MTA Kézirattárának Kornis Gyula és Révész Géza fondjai, valamint az interneten hozzáférhető Budapesti Tudományegyetemi Tanácsi, illetve Kari Tanácsi jegyzőkönyvek, s a jegyzőkönyvek jegyzékei az Eötvös Loránd Tudományegyetem (ELTE) Levéltárában. A jegyzőkönyvek az interneten hozzáférhetök erre a korra (Az Eötvös Loránd Tudományegyetem egyetemi vezetőtestületi jegyzőkönyvei, URL1), a szövegben csak az ülések dátumait adom meg.

A pszichológia huszadik század közepi sorsáról a Budapesti Tudományegyetemen két kép él, melyek közül én a másodikat képviselem.

\section{A KLASSZIKUS KÉP}

1918-19-ben, Révész Géza a forradalmak hullámán lesz alapítója a pszichológia tanszéknek. Ezt követi a forradalmak leverése után a pszichológia diszkreditációja. 1945-ben az egyetem újra meghívja a tanszék vezetésére Révész Gézát. Ezt valamilyen zürös, bizonytalan korszak követi 1947 és 1949 között, mert Révész nem vállalja el a megbízást. Majd 1949-ben Kardos Lajos vezetésével alakul újra a pszichológusképzés.

\section{A VALÓSÁG A PESTI BÖLCSÉSZKARON}

1918. szeptember végén, október elején az akkor már egy évtizede magántanár Révész Géza kétségtelenül alapító vezetője lesz a Lélektani Tanszéknek a Budapesti Tudományegyetemen, őt még azonban az utolsó király nevezte ki a posztra, 
$\mathrm{s}$ nem a forradalmak. Az is kétségtelen, hogy ezután aktívan részt vett az egyetem forradalmi újjászervezésében, és 1919 végétől volt valamiféle diszkreditáció mind az ő személyét, mind a pszichológiát illetően. Ugyanakkor, az 1920-as évek végétől, elsősorban Kornis Gyula kezdeményezésére (Harkai Schiller Pál például már 1930-ban doktorál a lélektani kategóriák rendszeréről), s Brandenstein Béla, a másik filozófiaprofesszor névleges gesztorálásával 1933-tól formailag is létrejött egy Lélektani Intézet, s egy ehhez kapcsolódó Lélektani Szeminárium, illetve Lélektani Tanulmányok könyvsorozat (Lénárd, 1991). Ezt azonban nem nevezték tanszéknek a kor szokásos egyetemi autonómiai gondolkodása mellett, ugyanis nem volt hozzákapcsolva professzor. A munkálatokat ténylegesen vezetö Harkai Schiller Pál (lásd róla Marton, 1996), mint az 1945 utáni vitákban többször visszatérnek rá, intézeti tanár és nem egyetemi tanár volt. Ez a mozzanat, hogy egy egyetemi tanárra van szükség, később, a szocialista, kommunista egyetemi fejlesztések felől nézve furcsának tủnik, de 1945 és 1949 között visszatérő kérdés volt. 1945-47 sávjában valóban meghívták Révész Gézát, s mivel ez a meghívás kudarcot vallott, egy ideig Várkonyi Hildebrand Dezsőt (1948-49-ben), a Szegedi Egyetem korábbi pszichológiai vezetőjét, kiugrott piaristát bízták meg, aki ekkor már a budapesti Müegyetem professzora. Végül azután, Várkonyi visszavonultatása, nyugdíjazása után, Kardos Lajos 1949-ben, a Nevelési Tanszékcsoportban találta meg a pszichológia folytatásának lehetőségét mint egyetemi docens.

\section{RÉVÉSZ GÉZA SZEREPE A BUDAPESTI EGYETEMI BÖLCSÉSZ-PSZICHOLÓGIÁBAN}

Révész Géza eredetileg budapesti jogász végzettségű (1902), majd Németországban, a legkiválóbb egyetemeken, Göttingenben és Berlinben pszichológiai képzettséget, majd pszichológiai doktori fokozatot szerzett fiatal zsidó értelmiségi, aki 1908-tól magántanár volt a budapesti tudományegyetemen, kapcsolatban mind az orvoskarral, mind a bölcsészkarral. A legenda szerint baloldali liberális zsidó révén, a forradalmi hatalom kivételezettje volt. A valóságban azonban, mint az 1. ábra mutatja, 1918. szeptember 28 -án még Károly király nevezte ki, ausztriai kastélyából, s Zichy János miniszter október 8-án értesítette erről Révészt (Pléh, 2009, 2010).

Ugyanakkor, a Pszichológia Tanszékre kinevezett Révész ténylegesen részt vett az egyetemi autonómia felszámolásában, az e körüli személyi és tanszékeket érintő harcokban, melyekről Litván György számolt be igen részletesen (Litván, 1968). Révészt azonban nehéz lett volna elmarasztalni, a forradalmak után is csak saját laboratóriumának gyors felszerelése, a gáz bevezetése miatt kritizálták, s levelezése tanúsága szerint egy évtizedig még emigrációja alatt is magyar útlevéllel élt (Pléh, 2009). Hollandiába emigrálva a modern holland pszichológia kialakításában vált évtizedekre döntő szereplővé Amszterdamban. Emellett Révész volt az első nem- 


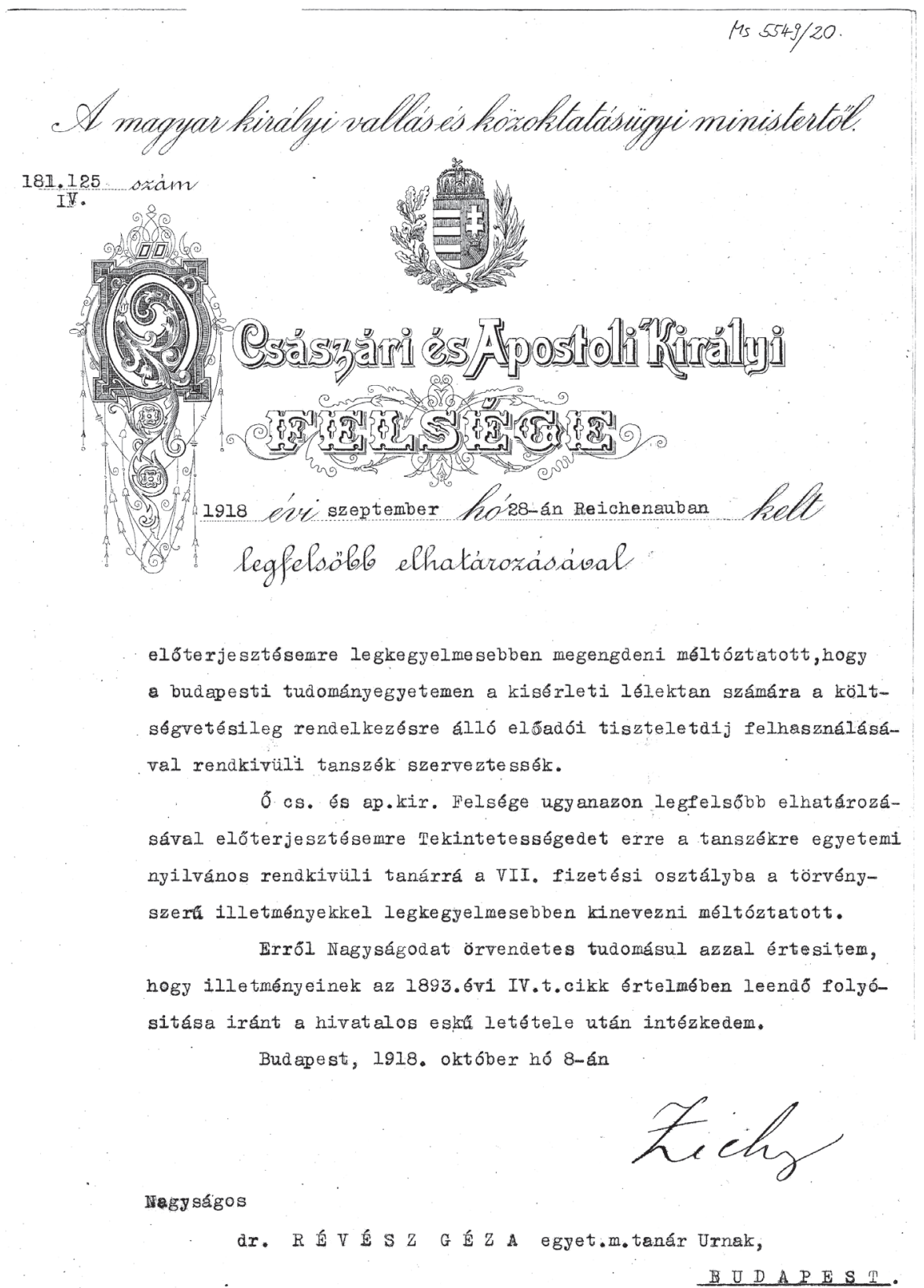

1. ábra. Révész Géza egyetemi tanári kinevező okmánya (MTA KIK Kézirattára, Révész Géza fond. Ms 5549/20. Az MTA KIK Kézirattára szíves engedélyével és segítségével) 
zetközi európai pszichológiai folyóirat, az Acta Psychologica elindítója 1935-ben, szintén Amszterdamban. Folyamatos maradt kapcsolata a magyar pszichológiai élettel és egykori kollégáival, munkatársaival, s számos egykori magyar kollégájának dolgozatait jelentette meg lapjában. Hermann Imre még 1950-ben is megjelenik a mentális folyamatok téri vonatkozásairól (a témát még Révész mellett kezdte el 1918-ban), s az állítólagosan a pszichoanalízissel szemben tartózkodó Révész ugyanebben a számban két további Magyarországról indult pszichoanalitikus, Székely Lajos és Alexander Ferenc/Franz dolgozatát közölte. Egykori munkatársként Hermann Imrével évtizedeken át leveleztek. Hermann végig Tanár Urazza Révészt.

Révésznek végig megmaradt tehát a kapcsolata a magyar pszichológiával, és a háború utáni újjáépítés éveiben többszöri levélváltásban mindig amellett állt ki, hogy a hagyományos egyetemi szerveződés és a hagyományos egyetemi autonómia elvének megfelelően rendkívül kompetens egyetemi vezetőkre van szükség. „Elméletileg és gyakorlatilag kiképzett tanárok és megfelelő segédszemélyzet az előfeltétel. Ha a tanári állásokat nem kompetens emberekkel töltik be, akkor ez évtizedekre megakadályozhatja a pszychológia egészséges fejlődését és a fiatal erők érvényesülését" (Gábor, 1991).

Révész kapcsolata a mai értelemben vett konzervatív értelmiségi körökkel is megmaradt. 1947-ben Révész Gézát a Magyar Tudományos Akadémia tagjává választotta Kornis Gyula, Prohászka Lajos és Szemere Samu felterjesztésére. Kornissal, a két világháború közötti kor hagyományos értelmezése szerint, konzervatív ideológusával, ugyanakkor pszichológusával, Révésznek végig megmaradt a kapcsolata. A két német iskolázottságú tudós örök barátságának számos dokumentumát látjuk. Hermann-nal összehasonlítva Kornis és Révész meghitten tegeződve leveleztek. Kornis a század első két évtizedében feltöltekezett német tudása elméleti jellegü, Révészé elsősorban kísérleti jellegü, de ugyanabban a közegben iskolázódtak, és ez fontos maradt egész életük során. Évtizedekkel később is megmaradt ez, azok után, hogy Révész a Tanácsköztársaság alatt egy kommunista diktatúrában, Kornis pedig mint rektor, államtitkár, felsőházi elnök, politikai szereplőként a Horthy-rendszer mellett exponálta magát. (Kornis politikusi és pszichológusi szerepéről Hunyady György 2016-os kötetében két adatgazdag s egyben értékelő tanulmány is szól.)

Amikor hosszas hányattatások után (akadémiai elnökség fél évig, majd egyetemi kétlépéses igazolás, visszafogadás, filozófiai professzorátus) Kornist nyugdíjazzák, Révész a következőket írja barátjának 1948 márciusában Amszterdamból:

„Kedves Barátom!

Értesültem, hogy nyugdíjazásodat kérted és, hogy előadásaidat beszüntetted. Nagyon kellemetlen hír volt, mert tudom, hogy a diákoknak szükségük volt a Te tanításodra, amely alapos filozófiai és psychológiai tudáson alapult, mely rendkívüli paedagógiai tudással párosult." 
A 2. ábra Kornis kitelepítési végzése, melyben mint horthysta képviselőházi alelnököt mindenétöl megfosztják. Ugyanakkor nem kell Karl Popper mélységü elemzés, hogy felismerjük a szabad társadalom ellenségeinek gondolkodásmódbeli és eljárási kontinuitását. A kommunista rendőrség sokszorosított iratkerete két 1939-es „horthysta” rendeletben találja meg a jogalapot a „horthysta politikus" kitelepítéséhez!

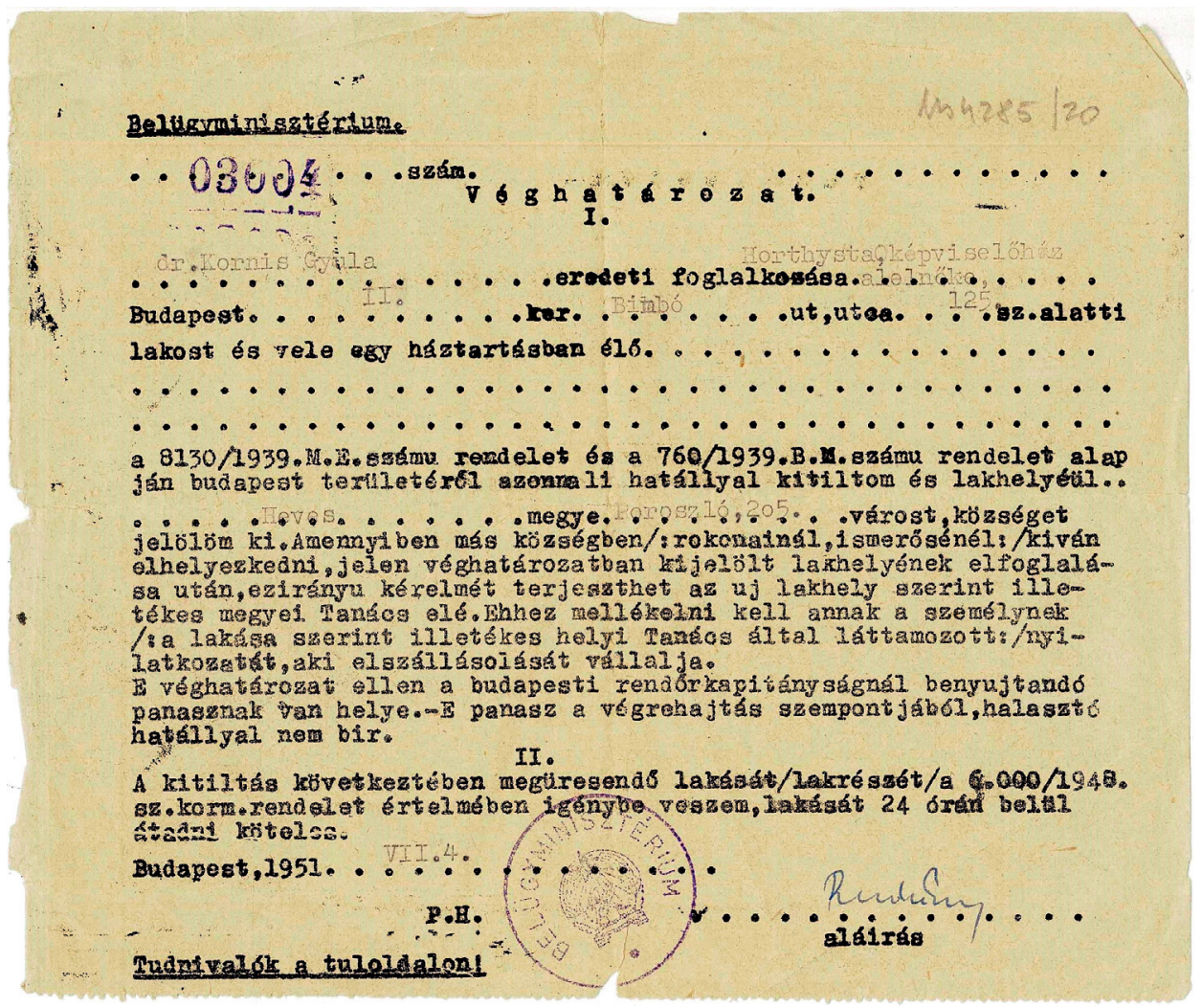

2. ábra. Kornis Gyula kitelepítési végzése

(MTA KIK Kézirattára, Kornis Gyula fond. Ms 5549/425. Az MTA KIK Kézirattára szíves segítségével és engedélyével)

A szenior tudósok közötti kapcsolat még a hidegháború évei alatt is megmaradt. Révész Amszterdamból ír erkölcsi támogató leveleket barátjának, és mind szakmai, mind emberi kérdésekről részletesen beszámolnak. 1954. december 29-én a Poroszlón kitelepítésben élő Kornis ezt írja barátjának, akitől egyébként a kor viszontagságainak közepette vitaminküldeményeket is kapott. 
„Kedves Jó Gézám!

Mélyen meghatott, hogy gyengélkedésed ellenére kiadós levéllel tiszteltél meg. Én szerencsétlen vagyok minden olyan levelemmel, amelyben valamely tudományos munkádat elemzem. Így tüzetesen írtam néhány hónapja klasszikus és magisztrális tanulmányodról, a Sprechen und denken-röl, de nem kaptad meg. Rendkívül élveztem nagyszerü problémaérzékedet, világos és kristálytiszta gondolatmeneted meggyőző logikáját és eredetiségét. Mindig tudsz újat mondani. Most ezt a levelet repülöpostán küldöm, hogy biztosan megkapd. Gyengélkedésed nagyon aggaszt, bár nem minősíted súlyosnak. A dec. 9. betöltött 76. év tiszteletreméltó kor ugyan, de legújabb munkáid sem árulnak el semmiféle szellemi fáradságot. Jómagam dec. 22-én léptem a 70-ik évembe. Az utolsó tíz év szenvedései és máig tartó anyagi bázis-nélkülisége megviselt. O. Wilde mondja a balladájában: »In the prison the Time assumes the form of Eternity. "Ezt jómagam is különösen érzem.

Örülök, hogy Veneziában oly jól érezted magadat s a linguisták, akik a könyvedből sokat tanultak, nagy számban fölkeresték a nagy szellemi magvetőt. Bolyai János agg korában írja jó barátjának, Gausnak (1853. II. 9.): »Gyakran vagyok Veled: emlékképeim, amelyeket arcképeddel együtt minden pusztulás között is megőriztem, az ismétlések da Capo al Segno ebben az életnek nevezett különös compositióban, ahol a sírás az ouverture, a hörgés a finale, $s$ közben-közben néhány régi accord, hogy ez még fájdalmasabbá tegye a legtöbb pokoli (disszonantiát).« Te és én nem vagyunk ilyen pesszimisták: az élet többet adott nekünk, semhogy már a finale-hörgést várnók. - A Te arcképedet a remek két unokával büszkén örzöm. - Magdának meleg üdvözletemet küldöm, Téged pedig a régi barátsággal ölellek [Kornis Gyula]” (MTA Kézirattára, Révész Géza fond. Ms 551/352, 1954. dec. 29).

\section{A LÉLEKTANI TANSZÉK FELÉ}

1945-ben, a megújuló szellemi életben számos kavargás, a politikai igazoló bizottságok müködése, az emigrációk, a baloldali erők megjelenése közepette, tehát egy igen zsúfolt korszakban is felmerült az igény a pszichológiai szakág újraszervezésére. Minden érintett érezte, hogy a háborúnak hatalmas pusztításai vannak mind az emberekben, mind a szervezetekben, mind az emberek gondolkodásában. A fasizmus és a háború pusztításai, valamint az önkéntes emigrációk nehezítették a pszichológia újjászervezését is. Jogi értelemben az egyetem a régi autonómiaelveket követi. Jogilag nincs újjászervezés, hiszen nincsen professzor sem. Eközben 1945-46-ban a Budapesti Egyetem, akárcsak a Szegedi Egyetem több potenciális pszichológiai vezetöje még mindig Kolozsvárott tanít, a régi majd az új magyar egyetemen. Például Harkai-Schiller Pál Budapeströl, s Várkonyi Hildebrand Dezső Szegedről. Ugyanakkor az egyetemi és minisztériumi vezetés 
részéről igen határozottak a várakozások a pszichológia felé. Az Egyetemi Tanács (1946. dec. 9.) a megüresedett Filozófia II. Tanszékre, Brandenstein Béla helyén szeretne létesíteni egy pszichológus vezetői állást. A kiírt pályázatra, melynek értékelő előadója egyébként Kornis Gyula volt, pszichológusok is bejelentkeztek, például Lénárd Ferenc és Noszlopy László, akik iránt Kornis nem volt túl lelkes. A filozófiai tanszéki professzori hely betöltéséért azonban nagy politikai küzdelem is indult, és végül, Lukács György javaslatára Fogarasi Béla, későbbi bölcsészkari dékán, majd közgazdasági rektor, a dialektikus logika képviselöje és kommunista ideológiai vezető kapott megbízást. Kornis integritására jellemző, hogy miközben ő Szemere Samu filozófust javasolta az állásra, Fogarasiról is igen alapos jelentést készített, még a Szovjetunióban született, orosz nyelvü, marxista föiskolai jegyzeteinek anyagát is feldolgozta, nyilván szlavista barátai segítségével. Fogarasi egyébként nagy múltú szerző volt, ha nem is az egyetemi, de a magyar filozófiai és felsőoktatás-politikai pályán. A liberális, majd baloldali fiatal az 1910-es években Henri Bergson és Bertrand Russell fordítója volt, majd a Vasárnapi és a Galilei Kör kapcsolatrendszerén keresztül a Tanácsköztársaság alatt a felsőoktatás minisztériumi átszervezője (és sakkügyi biztos). A Moszkvából hazatért emigránsnak éppen múltja miatt lett szerepe a pszichológia egyetemi sorsában. Kardos Lajos (1998) egy interjúban számolt be arról, hogy egykori Galilei Körbeli ismeretségük révén fordult a szorongatott pszichológia vezetőjeként Fogarasihoz, akivel az 1950-es évek elején megállapodtak abban, hogy a pavlovi tanuláskutatás müvelése elég releváns lesz pedagógiailag.

A Pszichológiai Tanszék s egyáltalán pszichológiai profil megjelenése felé vezető úton az Egyetemi és Kari Tanács dokumentumaiban számos erőfeszítés figyelhető meg. Az Egyetemi Tanács 1947. március 29-i és április 30-i ülésén foglalkozott a Pszichológia Tanszék kérdésével. Márciusban „Kiss Ferenc anatómus professzor, orvoskari dékán Révész Géza volt kari professzornak, jelenlegi Amszterdami egyetemi tanárnak meghívása iránt tett előterjesztést. Ezzel a lépéssel, Révész profeszszor egyúttal rehabilitáltatnék. A Kar, a Lélektani Tanszéknek, egyelöre az üresedésben lévő Filozófiai II. Tanszék terhére történő visszaállítását kéri.”

A Kari Tanács ülésén „A dékán jelenti, hogy a VK Miniszter úr leiratot intézett a karhoz, amelyben óhaját fejezte ki egy II. pedagógiai tanszék felállítása ügyében és kérte a kar javaslatát. [1947. március 14-től Ortutay Gyula a miniszter, P. Cs.] Túroczy ny. r. tanár kifejti, hogy amíg lélektani tanszék nincsen, addig ilyen katedra felállítása másodrangú kérdés. Szalai professzor javasolja, mivel a tanszéknek elsősorban a lélektani vonatkozásokat kell felölelnie, ennek keretében viszont az egész lélektan előadható, neveztessék az új tanszék nevelés-lélektani tanszéknek. Lukács professzor hivatkozva arra, hogy az ügymenet egy későbbi pontja szerint a felvetett lélektani tanszék ügyére úgy is sor kerül, kéri, hogy a Kar a két kérdést együtt tárgyalja. Kornis professzor a Miniszter leiratával kapcsolatban tájékoztatja a Kart Révész Gézáról és amszterdami intézetéről és a lé- 
lektani tanszék kérdésében bizottság kiküldetését kéri. A Kar ehhez hozzájárul. A Kar a bizottság tagjaiul Kornis, Prohászka, Lukács, Szalai, Turóczi, Zsirai, Német, Eckhardt és Laziczius ny. r. tanárokat küldi ki. Kornis ny. r. tanár egyben javasolja, hogy a Minisztérium által felvetett gondolatnak, amely szerint szorgalmazni kell külföldi magyar tudósoknak a magyar szellemi életbe való bekapcsolását, bővebb megvitatására ugyancsak bizottság küldessék ki."

A Bölcsészettudományi Kar 1947. július 1-jei ülésén intézkedik arról, hogy magát a pszichológiaoktatást heti három órában Kornis Gyula lássa el, ugyanakkor „A dékán ezután megemlékezik a Révész Géza professzornak nyújtandó elégtétel ügyéről. Az e célra összehívott lélektani- és filozófiai tanszék együttes bizottsága Révész Gézának a II. számú filozófiai tanszékre, mint legközelebbi rokon katedrára való meghívását javasolja még a jelen kari ülésben. Vadász Elemér ny.r. tanár javaslatot terjeszt elő Révész Gézának a lélektani tanszékre történő meghívására. Eszmecsere után, a dékán szavazásra teszi le a javaslatot. Beadatott 40 szavazat, ebből 38 igen, 1 nem, 1 pedig üres. A Kar tehát Révész Gézát a lélektani tanszékre ny. r. tanári minőségben meghívja. Amennyiben a Karnak a lélektani tanszék visszaállítására vonatkozó fenti kérése rövid időn belül nem volna teljesíthető, a Kar a II. számú filozófiai tanszékre vonatkozó igényének fenntartásával hozzájárul ahhoz, hogy a lélektani tanszék ideiglenesen a Révész Géza személyhez kötötten az üresedésben levő II. sz. filozófiai tanszék javadalmának terhére töltessék be. A Kar ennek megfelelően felkéri a VKM Urat, hogy a pályázatot a II. sz. filozófiai tanszékre egyelöre ne írja ki. Ügyben megbízza a dékánt, hogy a meghívás tényét közölje Révész professzorral.”

Révész Géza 1947 októberében, mintegy a rehabilitációja egyik lépéseként, Budapestre utazott. Feltehetően ekkor közölte végleg, hogy nem fogadja el a meghívást. Előadást tartott október 24-én az egyetemen amszterdami kutatási témájáról, a zsenialitás problémájáról, amely 1948-ban az Athenaeum lapban meg is jelent (Révész, 1947). 1947. június 6-án választották meg az MTA tagjává is, s ekkor írta a nyelv eredetéről szóló székfoglalóját, mely hatvan évvel később meg is jelent (Pléh, 2010).

Azért tételezhetjük fel, hogy Révész ekkor közölhette, hogy végleg nem jön vissza, mert 1947. október 31-én, egy héttel Révész egyetemi előadása után az Egyetemi Tanács meghívta Várkonyi Hildebrand Dezsőt. „A bölcsészettudományi kar előterjesztése a lélektani tanszék újjászervezése és betöltése ügyében. Előadó: Dr. MELLY JÓZSEF orvostudomány kari dékán. A bölcsészettudományi kar bizottságot küldött ki az 1919. óta betöltetlenül maradt lélektani tanszék betöltésére. A bizottság előadója: Dr. KORNIS GYULA nyilvános rendes tanár rámutatott arra a nagy jelentőségre, melyet a tanszék a bölcsészeti kar kutató és tanulmányi rendjében játszik. Javasolta a tanszék újraszervezését és annak Dr. VÁRKONYI HILDEBRAND közgazdaságtudomány kari professzor meghívása útján való betöltését. A bizottság az előadó javaslatát egyhangúan elfogadta." 
Várkonyi kinevezésének a Tudományegyetemre volt egy érdekes előzménye is. Várkonyi a Kolozsvári Egyetem magyar újraindítása során Szegedről Kolozsvárra ment (Séra, 2014). 1945-ben azután, a József Nádor Müszaki Egyetemen ,a Közgazdasági és Kereskedelmi Osztályhoz tartozó Neveléstudományi Tanszékre” egyetemi nyilvános rendes tanárrá nevezték ki (BME iratai 23-27/1945). Eközben Várkonyi javarészt még mindig Kolozsvárott tartózkodott, és az új egyetemen tanított. 1947-ben azonban, a miniszter kezdeményezésére áthelyezték a Budapesti Tudományegyetemre. A miniszter Ortutay Gyula Várkonyi régi ismerőse a Szegedi Egyetemröl, egykori diákja. A Müegyetem Tanácsának 1947. május 8-i ülésén az elnöklő rektor bejelentette, hogy Várkonyi Hildebrand egyetemi nyilvános rendes tanárnak tanszékével együtt a Pázmány Péter Tudományegyetemre való átadását feltétlenül szükségesnek tartja a miniszter úr.

Várkonyi rövid ideig, mintegy másfél évig volt aktív az egyetemen. 1948. szeptember 23-án, már a fordulat évében, éppen ő kezdeményezi a Bölcsészkari Tanácsban egy Kísérleti Pszichológia Tanszék felállítását. „A Bizottság javasolja, hogy a Kar tegyen előterjesztést a Tanszék felállítására, a betöltésre vonatkozóan pedig azt javasolja, hogy az pályázat útján történjék. A Kar a javaslatot elfogadja.” Ennek a javaslatnak lesz megvalósítója az a pályázat, amelynek nyertese Kardos Lajos kísérleti pszichológus lesz. Kardos előtte egy ideig a formailag még létező Lélektani Intézet vezetője volt mint docens (Borsodi-Tüskés, 2010, 205.).

\section{AZ IDŐK VÁLTOZÁSA: KÉT KARI TANÁCSI ÜLÉS ÖSSZEHASONLÍTÁSA}

A pszichológiát is érinti, hogy hogyan jelenik meg a fordulat évének nagy politikai harcvilága a Bölcsészkar kari tanácsaiban. Két év telik el az ironikusan összehasonlított két ülés között, s a szereplők szinte ugyanazok. Egy kari tanácsülés 1947. április 30-án két későbbi Nobel-díjasról dönt. Kornis Gyula előterjesztette Harsányi János félévbeszámítási kérelmét. „Folyamodó kéri, hogy 4 bölcsészet-kari, 6 orvoskari és 6 teológiai féléve alapján bölcsészdoktori szigorlatra bocsátassék. Előadó javasolja a kérés teljesítését. A szakosztály a javaslatot elfogadja.” Ez a Harsányi János lesz később a közgazdasági Nobel-emlékdíj kitüntetettje 1994-ben a nem együttmüködő játékok elméleti modellálásáért. Ekkor logikai hibákról írt, számos görög szöveggel tűzdelt doktori értekezést (kis része Harsányi, 1947), majd Szalay Sándor Szociológia Tanszékén lett gyakornok vagy tanársegéd. Ugyanezen az ülésen ,,a dékán bejelenti, hogy Békési György ny. r. egyetemi tanárt a Harvard Egyetem 1 évi tanulmányútra hívta meg. A Kar a további szabadságolásához hozzájárul.” Vagyis egy ülésen két későbbi Nobel-díjas ügye is szerepelt.

Nézzük meg az 1949. december 19-i ülést! „Végül dékán ünnepélyesen megemlékezik Sztálin generalisszimusz 70. születésnapjáról és javasolja, hogy a sztá- 
lini müszakot a szokottnál gondosabban takarított és feldíszített termekben az előadók és a hallgatók legtökéletesebb és legfegyelmezettebb munkájával fogja a Kar megvalósítani. Felkéri a kar tagjait, hogy minden igyekezetükkel emeljék e nap munkájának eredményességét. A Kar a javaslatot elfogadja. Dékán a jegyzökönyv hitelesítésére felkéri Németh Gyula, Túroczi Trostler József és Várkonyi Dezső ny. r. tanárokat és az ülést bezárja."

\section{A GYŐZTESEK VILÁGA}

Érdekes módon a kommunista fordulat után három, egymással is kapcsolatban lévő Szondi-tanítvány lett a magyar pszichológia átmentésének letéteményese. Várkony rövid életủ vezetése után Kardos Lajos lett hosszú időn át docensi beosztásban a pszichológia képviselője mint kísérleti pszichológus a Budapesti Egyetemen. Mérei Ferenc szintén Szondi-tanítvány. A később diszkreditált Mérei 1948-49-ben még csillogó nevelésügyi és tudománypolitikai vezető, az Országos Neveléstudományi Intézet igazgatója. Molnár Imre pedig, szintén Szondi-tanítvány, aki be is számolt a Szondi-hatásról s hármuk viszonyairól (Molnár, é. n.) 1948-tól 1962-ig a Gyermeklélektani Intézet igazgatója volt. Az igazi győztesek valójában, sok küzdelem közepette, azok az üldözött, a numerus clausus következtében francia, osztrák, német pszichológiai iskolázottságot s módszertani jártasságot szerzett, korábban hivatalosan nem szereplö Szondi-tanítványok, akik a háttérben élés majd bujkálás idején nagyon erős hálózatképző tudást alakítottak ki, miközben önálló pályájuk s érdeklődésük igen eltérö volt (kísérleti pszichológia, gyermeklélektan, müvészet és munkalélektan). Olyan hálózatképzést és olyan baloldali kapcsolatrendszert építettek fel, amely lehetővé tette maguk és intézményük túlélését a nehéz időkben.

\section{IRODALOM}

Borsodi Cs. - Tüskés A. (2010): Az Eötvös Loránd Tudományegyetem Bölcsészettudományi Karának története képekben 1635-2010. Budapest: ELTE, http://real.mtak.hu/7590/1/1.1.3.pdf

Gábor É. (1991): Révész Géza (1888-1955). In: Kiss György (szerk.): Tanulmányok a magyar pszichológia történetéből. Budapest: Akadémiai Kiadó, 24-36.

Harsányi J. (1947): A filozófiai tévedések logikai alkata. Athenaeum, 33, 33-38. http://real-j.mtak. hu/2041/1/Athenaeum_1947.pdf

Hermann I. (1950): Rapports spatiaux de quelques phenomenes psychiques. Acta Psychologica, 7 , 225-246. DOI: 10.1016/0001-6918(50)90016-3

Hunyady Gy. (2006a): A budapesti tudományegyetem és a pszichológia. In: Hunyady Gy.: A szociálpszichológia történeti olvasatai. Budapest: Eötvös Kiadó, 187-198.

Hunyady Gy. (2006b): Hetvenöt év és a magyar pszichológia. In: Hunyady Gy.: A szociálpszichológia történeti olvasatai. 199-212. 
Hunyady Gy. (2016): Jelentörténeti szociálpszichológia. Budapest: Eötvös Kiadó, http://ppkteszt. elte.hu/file2/HunyadyJelentortenet_final_online.pdf

Kardos L. (1998): Élmények, barátok örömök. Interjú Kardos Lajossal. In: Pléh Cs.: Hagyomány és újítás a pszichológiában. Budapest: Balassi Kiadó, 231-237.

Lénárd F. (1991): Az Egyetemi Lélektani Intézet 1932-1947 között végzett munkájáról. In: Kiss Gy. (szerk.): Tanulmányok a magyar pszichológia történetéböl. Budapest: Akadémiai Kiadó

Litván Gy. (1968): A forradalmi kormány és a budapesti tudományegyetem erőpróbája 1918-1919 fordulóján. Történelmi Szemle, 11, 401-427. https://tti.btk.mta.hu/images/kiadvanyok/folyoiratok/tsz/tsz1968_4/litvan.pdf

Marton M. (1996): Harkai Schiller tudományos szemlélete harminc év néhány felismerésének tükrében. Pszichológia, 16, 115-131.

Molnár I. (é. n.): Ami a kulisszák mögött volt a magyar pszichológiában a XX. század közepén. Kézirat

Pléh Cs. (2009): A korai magyar kísérleti pszichológia és a nagyvilág. Révész Géza emlékére. Magyar Pszichológiai Szemle, 64, 467-495. https://bit.ly/35NT7cg

Pléh Cs. (2010): Révész Géza: a sors feszültségei levelezése s székfoglalója tükrében. Thalassa, 20, 75-100. http://imago.mtapi.hu/a_folyoirat/e_szovegek/pdf/(20)2009_4/075-100_Pleh-Cs_Revesz-Gezarol.pdf

Révész G. (1947): A zsenialitás problémájáról. Athenaeum, 33, 8-15. http://real-j.mtak.hu/2041/1/ Athenaeum_1947.pdf

Séra L. (2014): Fordulópontok az erdélyi magyar pszichológia történetében. Magyar Pszichológiai Szemle, 69, 761-795. DOI: 10.1556/MPSzle.69.2014.4.7, http://real.mtak.hu/43067/

URL1: Az Eötvös Loránd Tudományegyetem egyetemi vezetötestületi jegyzőkönyvei: https://library.hungaricana.hu/hu/collection/egyetemi_jegyzokonyvek_elte/ 